\title{
Can metformin limit weight gain in the obese with pregnancy?
}

\section{Eman Ali Abd El Fattah*}

Department of obstetrics and gynecology, Alexandria faculty of Medicine, Azareeta, Alexandria, Egypt

Received: 18 January 2016

Accepted: 15 February 2016

\section{*Correspondence:}

Dr. Eman Ali Abd El Fattah,

E-mail: eman0eman0eman7@gmail.com

Copyright: (C) the author(s), publisher and licensee Medip Academy. This is an open-access article distributed under the terms of the Creative Commons Attribution Non-Commercial License, which permits unrestricted non-commercial use, distribution, and reproduction in any medium, provided the original work is properly cited.

\begin{abstract}
Background: Maternal overweight and obesity is associated with many obstetric complications. Obesity is linked to insulin resistance. Improving insulin sensitivity may therefore account for weight reduction. Metformin was found to be effective in type 2 diabetes and polycystic ovarian syndrome through improving insulin sensitivity. Several studies proved its efficacy in the obese non- pregnants, but its role during pregnancy is not yet well-established. In this study, we are testing the ability of metformin to limit weight gain with pregnancy and therefore reducing complications as gestational Diabetes and hypertension.

Methods: A prospective study was conducted in Alexandria, Egypt. The study was registered in the South African Cochrane Centre under an identification number PACTR201505001142202. Two Hundreds participants with a BMI of $\geq 35 \mathrm{Kg} / \mathrm{m}^{2}$, pregnant in the early second trimester, were equally divided into two groups; in which group 1 will receive metformin $500 \mathrm{mg}$ twice a day and group 2 will receive placebo. Prior to inclusion, $75 \mathrm{~g}$ oral glucose tolerance test, fasting insulin, fasting blood glucose, $1 \mathrm{~h}$ and $2 \mathrm{~h}$ glucose blood and HbA1C were measured .Both groups were followed up monthly for weight and for pregnancy complications namely gestational diabetes and preeclampsia till 36 weeks of pregnancy.

Results: There was a significant difference in the weight gain and the one hour blood sugar measurement between the two groups, but not in the occurrence of pregnancy complications namely gestational diabetes and hypertension.

Conclusions: Metformin succeeded to limit weight gain the obese with pregnancy.
\end{abstract}

Keywords: Pregnancy, Weight gain, Metformin

\section{INTRODUCTION}

Maternal overweight and obesity are the most common high-risk obstetric conditions. ${ }^{1}$ During pregnancy, fat is preferentially deposited in the femoral and abdominal regions. $^{2}$

Regional fat distribution may differ for women already overweight or obese before pregnancy. Obese women experience more variable changes, including lower or higher gestational weight gains and lower or similar gestational fat gains, but have greater increases in central adiposity and fat deposition during the postpartum period when compared with lower BMI groups. ${ }^{3}$
Scientists have postulated that the major determinant of body fat distribution is insulin resistance. Normally, fat is deposited in subcutaneous adipose stores. It is hypothesized that as fat stores increase, so does insulin resistance, limiting further deposition in the subcutaneous stores. This leads to increased uptake of triglycerides into visceral stores and other ectopic sites such as hepatic sites and others. $^{4-9}$

Human pregnancy is characterized by a series of metabolic changes that promote adipose tissue accretion in early gestation, followed by insulin resistance and facilitated lipolysis in late pregnancy. In early pregnancy, insulin secretion increases, while insulin sensitivity is 
unchanged, decreased, or may even increase. However, in late gestation, maternal adipose tissue depots decline, while postprandial free fatty acid (FFA) levels increase and insulin-mediated glucose disposal worsens by 40 $60 \%$ compared with pre pregnancy. The ability of insulin to suppress whole-body lipolysis is also reduced during late pregnancy ${ }^{10}$ and this is further reduced in GDM subjects, ${ }^{11}$ contributing to greater postprandial increases in FFAs, increased hepatic glucose production and severe insulin resistance. ${ }^{12-16}$

Although various placental hormones have been suggested to reprogram maternal physiology to meet foetal needs, the cellular mechanisms for this complex transition remain obscure. ${ }^{16}$ However, it is important to note that, with the exception of tumour necrosis factor (TNF)- $\alpha$, changes in placental hormones in human pregnancy do not directly correlate with changes in maternal insulin resistance Therefore, a synergy with other obesity or pregnancy-related factors may hold the key to understanding how insulin resistance develops during pregnancy. ${ }^{17}$

Recent prospective studies have implicated adiponectin from adipocytes and secreted factors, such as TNF- $\alpha$, as active candidates in mediating insulin resistance of pregnancy. Collectively, these factors, known as "adipokines," include leptin, adiponectin, TNF- $\alpha$, interleukin-6, resistin, and others. Obese humans show a positive correlation between TNF- $\alpha$ levels and BMI and hyperinsulinemia. $^{18-20}$

Adiponectin is a secreted globular protein synthesized exclusively in adipocytes. In humans, low plasma adiponectin concentrations correlate highly with insulin resistance in obesity, type 2 diabetes, and gestational Diabetes mellitus GDM. ${ }^{21-23}$ Recent findings also show that adiponectin secretion and adiponectin mRNA levels in white adipose tissue decline with advancing gestation, even in lean women suggesting that there are pregnancyassociated factors that reduce adiponectin levels. ${ }^{24}$

Circulating levels of adiponectin have been shown to correlate with whole-body insulin sensitivity, presumably working through adiponectin receptors in skeletal muscle and liver. ${ }^{25}$ Adiponectin stimulates glucose uptake in skeletal muscle and reduces hepatic glucose production through its effect on AMP-activated protein kinase. Thus, adiponectin can be viewed as an endogenous insulinsensitizing hormone. Several studies have demonstrated that adiponectin levels are lower during late pregnancy. ${ }^{26-}$ 31

According to these phenomena, insulin resistance of normal pregnancy is multifactorial, involving reduced ability of insulin to phosphorylate the insulin receptor, subclinical inflammation, placental hormones, reduced adiponectin secretion, and excess lipolysis.
Metformin is a bigaunide that decreases hepatic glucose output by inhibiting gluconeogenesis and enhancing peripheral glucose uptake. It also decreases intestinal glucose absorption and increases insulin sensitivity.

It is a well- established anti-diabetic drug, which has been used from the late 1950s on and still first line therapy in type 2 diabetes. ${ }^{32,33}$

Metformin reduces insulin resistance which is the underlying cause of both type 2 diabetes and PCOS. ${ }^{34,35,43,44}$ Metformin has been observed to cause weight loss in type 2 diabetes patients. ${ }^{36,37}$

Obesity in non-diabetic patients is also linked to insulin resistance. ${ }^{38-40}$ Improving insulin sensitivity may account for weight reduction under metformin therapy, although the exact underlying patho mechanisms are unclear. ${ }^{37,41,42}$

Efficacy of metformin to reduce weight in a standardized setting has been tested in few randomized trials, data on its effectiveness in the obese nondiabetic during pregnancy, and on the foetus are still lacking. If in fact less visceral and ectopic fat in the foetus may signal reduced insulin resistance, therefore there may be a longterm benefit from in utero metformin exposure which is not yet proved. ${ }^{45}$

\section{METHODS}

A prospective study was conducted in El Shatby maternity hospital, Alexandria, Egypt after the approval of the ethics committee of Alexandria university, the study was registered in the south African Cochrane Centre under an identification number PACTR201505001142202. Two Hundreds pregnant participants with a BMI of $\geq 35 \mathrm{Kg} / \mathrm{m}^{2}$, in the early second trimester, were offered to participate. Prior to inclusion, a $75 \mathrm{~g}$ oral glucose tolerance test was performed. Blood glucose, HbA1C and plasma insulin levels were measured at baseline, $1 \mathrm{~h}$ and $2 \mathrm{~h}$ after glucose ingestion. ${ }^{46}$ All participants had normal levels irrespective of the degree of insulin sensitivity.

Participants were divided into two groups;

Group 1: Hundred participants received metformin in a dose of $500 \mathrm{mg}$ twice a day.

Group 2: Hundred participants received placebo.

Both groups were followed up monthly for weight and for the development of pregnancy complications namely gestational Diabetes and pre-eclampsia till 36 weeks. Periodic ultrasonographic fetal weight estimation was also done.

The aim of the study is to evaluate if metformin in the obese pregnant will limit weight gain and thereby decreasing obesity risks with pregnancy especially pre- 
eclampsia and gestational diabetes, and also to evaluate if its use will affect the fetal weight or not.

\section{RESULTS}

A total of 200 participants were included in the study. The average age was 26 years. The average dose of metformin was $1000 \mathrm{mg}$ daily in the metformin-treated group ranging from $500 \mathrm{mg}$ to $1500 \mathrm{mg}$ depending on the original body mass index.

Only $15(15 \%)$ patients under metformin complained of gastrointestinal side effects which were well tolerated and they continued the drug. Monthly ultrasonographic evaluation of the foetal weight was done and the estimated foetal weight for all the participants matched with the percentile for foetal age.

\section{Statistical procedure}

Data were collected and entered to the computer using SPSS (Statistical Package for Social Science) program for statistical analysis (ver 20). Data were entered as numerical or categorical, as appropriate. Parametric statistics (minimum and maximum, mean, standard deviation) and comparison using independent t-test was carried out. Chi-squared test (Fisher Exact) was used for analysis of association. In the present study an alpha level was set to $5 \%$ with a significance level of $95 \%$, and a beta error accepted up to $20 \%$ with a power of study of $80 \%{ }^{7}$

Table 1 displays the age, BMI and basal investigations in the two studied groups.

Table 1: Age, BMI and basal investigations in the two studied groups.

\begin{tabular}{|c|c|c|c|}
\hline & Metformin group ( $n=100)$ & Placebo group (n=100) & Significance \\
\hline $\begin{array}{l}\text { Age (years) } \\
\text { Minimum-Maximum } \\
\text { Mean } \pm \text { S.D. }\end{array}$ & $\begin{array}{l}18-37 \\
26.92 \pm 5.20\end{array}$ & $\begin{array}{l}17-38 \\
26.20 \pm 5.51\end{array}$ & $\begin{array}{l}\mathrm{t}=0.950 \\
\mathrm{p}=0.343 \mathrm{NS}\end{array}$ \\
\hline $\begin{array}{l}\boldsymbol{B M I}\left(\mathbf{k g} / \mathrm{m}^{2}\right) \\
\text { Minimum-Maximum } \\
\text { Mean } \pm \text { S.D. }\end{array}$ & $\begin{array}{l}35.00-38.30 \\
36.42 \pm 1.04\end{array}$ & $\begin{array}{l}35.00-38.00 \\
36.17 \pm 0.99\end{array}$ & $\begin{array}{l}\mathrm{t}=1.759 \\
\mathrm{p}=0.080 \mathrm{NS}\end{array}$ \\
\hline $\begin{array}{l}\text { Fasting blood glucose }(\mathrm{mg} / \mathrm{dl}) \\
\text { Minimum-Maximum } \\
\text { Mean } \pm \text { S.D. }\end{array}$ & $\begin{array}{l}57.00-87.00 \\
72.73 \pm 8.47\end{array}$ & $\begin{array}{l}57.00-89.00 \\
71.29 \pm 8.83\end{array}$ & $\begin{array}{l}\mathrm{t}=1.176 \\
\mathrm{p}=0.241 \mathrm{NS}\end{array}$ \\
\hline $\begin{array}{l}\text { 1-hour PPBG }(\boldsymbol{m g} / \boldsymbol{d l}) \\
\text { Minimum-Maximum } \\
\text { Mean } \pm \text { S.D. }\end{array}$ & $\begin{array}{l}89.00-142.00 \\
107.55 \pm 13.12\end{array}$ & $\begin{array}{l}90.00-138.00 \\
114.31 \pm 13.27\end{array}$ & $\begin{array}{l}\mathrm{t}=3.621 \\
\mathrm{p}=0.000 *\end{array}$ \\
\hline $\begin{array}{l}\text { 2-hour PPBG }(\mathbf{m g} / d l) \\
\text { Minimum-Maximum } \\
\text { Mean } \pm \text { S.D. }\end{array}$ & $\begin{array}{l}85.00-125.00 \\
95.86 \pm 6.73\end{array}$ & $\begin{array}{l}85.00-116.00 \\
97.09 \pm 7.36\end{array}$ & $\begin{array}{l}\mathrm{t}=1.233 \\
\mathrm{p}=0.219 \mathrm{NS}\end{array}$ \\
\hline $\begin{array}{l}\text { Fasting insulin } \\
\text { Minimum-Maximum } \\
\text { Mean } \pm \text { S.D. }\end{array}$ & $\begin{array}{l}6.90-9.00 \\
8.10 \pm 0.59\end{array}$ & $\begin{array}{l}5.90-9.00 \\
7.99 \pm 0.75\end{array}$ & $\begin{array}{l}\mathrm{t}=1.130 \\
\mathrm{p}=0.260 \mathrm{NS}\end{array}$ \\
\hline $\begin{array}{l}\text { HbA1C }(\%) \\
\text { Minimum-Maximum } \\
\text { Mean } \pm \text { S.D. }\end{array}$ & $\begin{array}{l}5.90-8.70 \\
7.28 \pm 0.77\end{array}$ & $\begin{array}{l}5.30-8.70 \\
7.16 \pm 0.91\end{array}$ & $\begin{array}{l}\mathrm{t}=0.995 \\
\mathrm{p}=0.321\end{array}$ \\
\hline
\end{tabular}

$\mathrm{t}$ : independent $\mathrm{t}$ test, $\mathrm{p}$ : probability of error $($ alpha $=0.05)$

There was no difference in age between the two groups where the $\mathrm{p}$ was $\mathrm{p}=0.343$ and no significant difference in body mass index between the two groups where the $\mathrm{p}$ was 0.080. Basal investigations showed no significant difference in fasting blood sugar, fasting insulin, and 2 hour postprandial blood sugar but there was a significant difference in the one hour postprandial blood sugar between the two groups where the $\mathrm{p}$ was $=0.000$ There was no significant difference in the haemoglobin $\mathrm{A} 1 \mathrm{c}(\mathrm{p}=$ $0.321)$.

Table 2 and figure 1 displays the weight gain between the two groups, a significant reduction in weight gain in the metformin group compared to the other group where the mean was 6.55 for the metformin group and 11.61 for the other group.

The limitation in weight gain in the metformin treated group was significant as compared to the control ( $p$ 0.000 ) which proved the effect of metformin in limiting weight gain.

Table 3 displays Pregnancy complications in the two studied groups. 
Table 2: Weight gain in the two studied groups.

\begin{tabular}{|llll|}
\hline & $\begin{array}{l}\text { Metformin } \\
\text { group } \\
(\mathrm{n}=100)\end{array}$ & $\begin{array}{l}\text { Placebo } \\
\text { group } \\
(\mathrm{n}=100)\end{array}$ & Significance \\
$\begin{array}{l}\text { Weight gain } \\
\text { (kg) }\end{array}$ & & $6-18$ & \\
$\begin{array}{l}\text { Minimum - } \\
\text { Maximum } \\
\text { Mean } \pm \text { S.D. }\end{array}$ & $0.50-13$ & $\begin{array}{l}11.61 \pm \\
\mathrm{t}=12.957\end{array}$ & $\mathrm{p}=0.000$ \\
\hline
\end{tabular}

$\mathrm{t}$ : independent $\mathrm{t}$ test, $\mathrm{p}$ : probability of error $(\mathrm{alpha}=0.05)$

Table 3: Pregnancy complications in the two studied groups.

\begin{tabular}{|llll|}
\hline & $\begin{array}{l}\text { Metformin } \\
\text { group } \\
(\mathrm{n}=100)\end{array}$ & $\begin{array}{l}\text { Placebo } \\
\text { group } \\
(\mathrm{n}=100)\end{array}$ & Significance \\
\hline $\begin{array}{l}\text { Hypertension } \\
\mathrm{n}(\%)\end{array}$ & $2(2 \%)$ & $6(6 \%)$ & $\begin{array}{l}\mathrm{P}(\mathrm{FE})= \\
0.279 \mathrm{NS}\end{array}$ \\
\hline $\begin{array}{l}\text { Gestational } \\
\text { diabetes } \mathrm{n}(\%)\end{array}$ & $2(2 \%)$ & $6(6 \%)$ & $\begin{array}{l}\mathrm{P}(\mathrm{FE})= \\
0.279 \mathrm{NS}\end{array}$ \\
\hline
\end{tabular}

$\mathrm{p}(\mathrm{FE})$ : probability of Fisher exact test

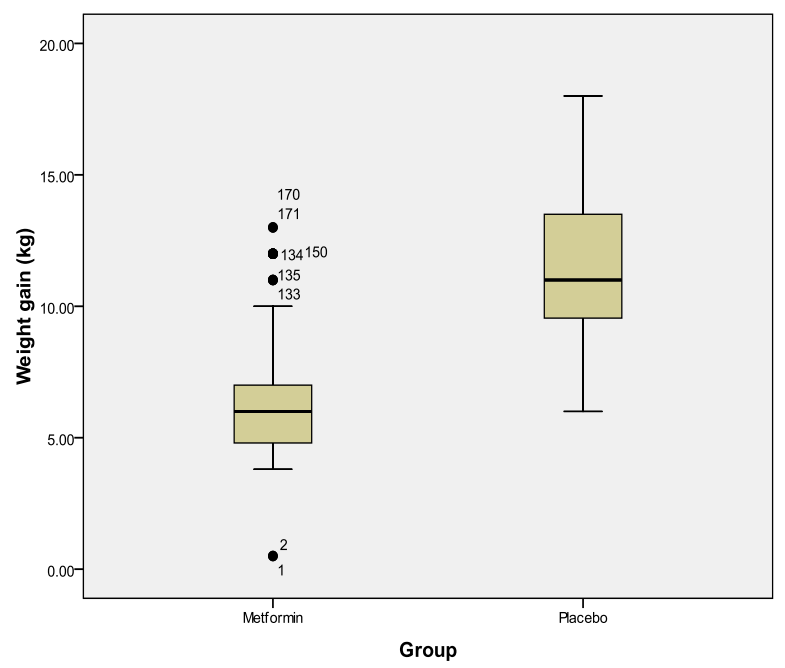

Figure 1: Box and whisker graph of weight gain (kg) in the two studied groups, the thick line in the middle of the box represents the median, the box represents the inter-quartile range (from $25^{\text {th }}$ to $75^{\text {th }}$ percentiles), the whiskers represents the minimum and maximum values after excluding outliers (black-filled circle) and extremes (asterisks).

Gestational diabetes and hypertension were less in the metformin group compared to the other group, only two cases came with gestational diabetes among metformin users compared to six cases among the non- users, the same with hypertension, but this difference was not statistically significant where the $p$ was 0.279 for hypertension and $\mathrm{p}$ was 0.279 for diabetes.

\section{DISCUSSION}

In our study we found an average weight gain of $6.55 \mathrm{~kg}$ under treatment with metformin for 6 months started at twelve weeks gestation and ended at thirty six weeks gestation in overweight and obese pregnant participants, mostly insulin-resistant compared to an average weight gain of $11.61 \mathrm{~kg}$ without metformin which was statistically significant.

Although metformin is clinically recognized as a weight reducing agent, there is little evidence in the literature supporting this knowledge. 47,48

Some researchers used metformin for a short duration ranging from 15 days to 3 months in 6 out of 9 studies, the Body mass index of the participants was limited to overweight (BMI $25-29.9 \mathrm{~kg} / \mathrm{m}^{2}$ ) or grade I obesity (BMI $\left.30-34.9 \mathrm{~kg} / \mathrm{m}^{2}\right)$, therefore severe insulin resistance in these patients was unlikely and these studies were conducted on non- pregnant subjects. No decrease in weight was noticed with metformin. ${ }^{49}$

Other studies investigated metformin in women suffering from PCOS with base line weight of $97.0 \mathrm{~kg}$ (Gamberini et al) reported an insignificant weight reducing effect of metformin. ${ }^{50-53}$

In this study, patients were on a hypocaloric diet before metformin was started. The only possible explanation for the insignificant effect of metformin is the diminished insulin resistance produced by the hypocaloric diet. ${ }^{54}$ Also the dosage of metformin was only $850 \mathrm{mg}$ daily.

In our study, we increased the dose of metformin depending on the weight of the patient up to $1500 \mathrm{mg}$ per day with an average dose $1000 \mathrm{mg}$ per day and the participants were not on diet.

On the contrary, other studies proved a role for metformin in reducing weight where a weight loss of $6 \mathrm{~kg}$ was described in severely obese patients with mostly elevated fasting insulin levels (base line weight $117.3 \mathrm{~kg}){ }^{55}$

Another study observed in obese type 2 diabetes patients -insulin resistant a weight loss of $8 \mathrm{~kg}$ after metformin treatment used for 24 weeks. ${ }^{56}$

In a study by Mogul et al, 25 out of 26 hyperinsulinemic, severely obese women lost weight of at least $5 \%$ within 6 months of metformin therapy. Hyperinsulinemia of these patients indicates insulin resistance making them more sensitive to effects of metformin on body weight. ${ }^{57}$

These data suggests that the efficacy of metformin to reduce weight depends on the degree of insulin resistance explained by the fact that insulin-receptor binding, the tyrosine kinase activity of insulin receptor and glucose 
transport are altered in the same way in type 2 diabetes patients and comparably obese individuals without diabetes, supporting the efficacy of metformin in both conditions matching with our results when metformin was given to the obese with pregnancy. ${ }^{58}$

Carbohydrate and lipid metabolism change during pregnancy to ensure a continuous supply of nutrients to the fetus. ${ }^{59}$ In early pregnancy, glucose tolerance is normal or improved slightly, and peripheral sensitivity to insulin and hepatic basal glucose production are normal or increase by $15 \% .{ }^{60-62}$ As pregnancy advances, nutrientstimulated insulin responses increase progressively despite only minor deterioration in glucose tolerance, which is consistent with progressive insulin resistance. ${ }^{63}$ In late pregnancy, insulin action is 50-60 percent lower than in non- pregnant state. ${ }^{64,65}$ By the third trimester, basal and 24-hour mean insulin concentrations may double. ${ }^{66}$ The first and second phases of insulin release increase threefold by late pregnancy. ${ }^{60}$ These alterations in maternal insulin sensitivity affect both glucose and lipid metabolism resulting in a decreased ability of insulin to suppress lipolysis. ${ }^{67}$

Metformin improves blood glucose control by insulinstimulated glucose disposal in skeletal muscle, decreases hepatic glucose output inhibits gluconeogenesis and decreases intestinal glucose absorption from the gastrointestinal tract providing less glucose for energy storage in adipose tissue.

Metformin also decreases appetite ${ }^{37,68}$ and certain authors stated that metformin contains a primary anorectic factor. ${ }^{69}$ One other reason may be a decrease of leptin levels suggesting an underlying improvement of leptin resistance. $^{70,71}$

\section{CONCLUSIONS}

Metformin in high enough doses is a beneficial and cost effective drug to limit weight gain in the obese during pregnancy.

\section{ACKNOWLEDGEMENTS}

Many thanks to the nursing team of fetomaternal clinic in El Shatby Maternity hospital for their co-operation. Many thanks to professor doctor El Sayed Amr for his help in statistics.

Funding: No funding sources

Conflict of interest: None declared

Ethical approval: The study was approved by the Institutional Ethics Committee

\section{REFERENCES}

1. Catalano PM. Increasing maternal obesity and weight gain during pregnancy: the obstetric problems of plentitude. Obstet Gynecol. 2007;110:743-4
2. Sidebottom AC, Brown JE, Jacobs DR Jr. Pregnancy-related changes in body fat. Eur J Obstet Gynecol Reprod Biol. 2001;94:216-23.

3. Soltani H, Fraser RB. A longitudinal study of maternal anthropometric changes in normal weight, overweight, and obese women during pregnancy and postpartum. Br J Nutr. 2000;84:95-101.

4. Dabelea D, Hanson RL, Lindsay RS, Pettitt DJ, Imperatore G, Gabir MM et al. Intrauterine exposure to diabetes conveys risks for type 2 diabetes and obesity: a study of discordant sibships. Diabetes 2000;49:2208-11.

5. Dabelea D. The predisposition to obesity and diabetes in offspring of diabetic mothers. Diabet Care. 2007;30(2):S169-74.

6. Dyer JS, Rosenfeld CR, Rice J, Rice M, Hardin DS. Insulin resistance in hispanic large-for-gestationalage neonates at birth. J Clin Endocrinol Metabol. 2007;92:3836-43.

7. Rowan JA, Rush EC, Obolonkin V, Battin M, Wouldes T, Hague WM. Metformin in Gestational diabetes: The offspring follow-up (MiG TOFU): body composition at 2 years of age. Diabet Care. 2011;34:2279-84.

8. Ali AT, Ferris WF, Naran NH, Crowther NJ. Insulin resistance in the control of body fat distribution: a new hypothesis. Horm Metab Res. 2011;43:77-80.

9. Silverman BL, Metzger BE, Cho NH, Loeb CA Impaired glucose tolerance in adolescent offspring of diabetic mothers: relationship to fetal hyperinsulinism. Diabetes Care. 1995;18:611-7.

10. Catalano PM, Nizielski SE, Shao J, Preston L, Qiao L, Friedman JE. Down regulated IRS-1 and PPAR gamma in obese women with gestational diabetes: relationship to FFA during pregnancy. Am J Physiol Endocrinol Metab. 2002;282:E522-33.

11. Friedman JE, Ishizuka $\mathrm{T}$, Shao J, Huston $\mathrm{L}$, Highman T, Catalano P. Impaired glucose transport and insulin receptor tyrosine phosphorylation in skeletal muscle from obese women with gestational diabetes. Diabetes. 1999;48:1807-14.

12. Catalano PM, Huston L, Amini SB, Kalhan SC. Longitudinal changes in glucose metabolism during pregnancy in obese women with normal glucose tolerance and gestational diabetes mellitus. Am J Obstet Gynecol. 1999;180:903-16.

13. Homko CJ, Sivan E, Reece EA, Boden G. Fuel metabolism during pregnancy. Semin Reprod Endocrinol. 1999;17:119-25.

14. Cho NH, Roston SM, Radvany R. Pre-pregnancy weight and antepartum insulin secretion predict glucose tolerance five years after gestational diabetes mellitus. Diabet Care. 1993;16:1598-605.

15. Buchanan TA, Xiang AH, Kjos SL, Trigo E, Lee WP, Peters RK. Antepartum predictors of the development of type 2 diabetes in Latino women 1126 months after pregnancies complicated by gestational diabetes. Diabetes. 1999;48:2430-6.

16. Handwerger S, Freemark M. The roles of placental growth hormone and placental lactogen in the 
regulation of human fetal growth and development. J Pediatr Endocrinol Metab. 2000;13:343-56.

17. Kirwan JP, Hauguel-De Mouzon S, Lepercq J, Challier JC, Huston-Presley L, Friedman JE, Kalhan $\mathrm{SC}$, Catalano PM. TNF-alpha is a predictor of insulin resistance in human pregnancy. Diabetes. 2002;51:2207-13.

18. Hotamisligil GS, Spiegelman BM. Tumor necrosis factor alpha: a key component of the obesity-diabetes link. Diabetes. 1994;43:1271-8.

19. Peraldi P, Hotamisligil GS, Buurman WA, White MF, Spiegelman BM. Tumor necrosis factor (TNF)alpha inhibits insulin signaling through stimulation of the p55 TNF receptor and activation of sphingomyelinase. J Biol Chem. 1996;271:13018-22.

20. Hotamisligil GS, Peraldi P, Budavari A, Ellis R, White MF, Spiegelman BM. IRS-1-mediated inhibition of insulin receptor tyrosine kinase activity in TNF-alpha and obesity-induced insulin resistance. Science. 1996;271:665-8.

21. Weyer C, Funahashi T, Tanaka S, Hotta K, Matsuzawa Y, Pratley RE, Tataranni PA: Hypoadiponectinemia in obesity and type 2 diabetes: close association with insulin resistance and hyperinsulinemia. J Clin Endocrinol Metab. 2001;86:1930-5.

22. Worda C, Leipold H, Gruber C, Kautzky-Willer A, Knofler M, Bancher-Todesca D. Decreased plasma adiponectin concentrations in women with gestational diabetes mellitus. Am J Obstet Gynecol. 2004;191:2120-4.

23. Cseh K, Baranyi E, Melczer Z, Kaszas E, Palik E, Winkler G. Plasma adiponectin and pregnancyinduced insulin resistance. Diabetes Care. 2004;27:274-5.

24. Catalano PM, Hoegh M, Minium J, Huston-Presley L, Bernard S, Kalhan S, Hauguel-De Mouzon S. Adiponectin in human pregnancy: implications for regulation of glucose and lipid metabolism. Diabetologia. 2006;49:1677-85.

25. Hara K, Yamauchi T, Kadowaki T. Adiponectin: an adipokine linking adipocytes and type 2 diabetes in humans. Curr Diab Rep. 2005;5:136-40.

26. Winzer C, Wagner O, Festa A, Schneider B, Roden M, Bancher-Todesca D, Pacini G, Funahashi T, Kautzky-Willer A. Plasma adiponectin, insulin sensitivity, and subclinical inflammation in women with prior gestational diabetes mellitus. Diabetes Care. 2004;27:1721-7.

27. Heitritter SM, Solomon CG, Mitchell GF, SkaliOunis N, Seely EW. Subclinical inflammation and vascular dysfunction in women with previous gestational diabetes mellitus. J Clin Endocrinol Metab. 2005;90:3983-8.

28. Williams MA, Qiu C, Muy-Rivera M, Vadachkoria $\mathrm{S}$, Song $\mathrm{T}$, Luthy DA. Plasma adiponectin concentrations in early pregnancy and subsequent risk of gestational diabetes mellitus. J Clin Endocrinol Metab. 2004;89:2306-11.
29. Ranheim T, Haugen F, Staff AC, Braekke K, Harsem NK, Drevon CA. Adiponectin is reduced in gestational diabetes mellitus in normal weight women. Acta Obstet Gynecol Scand. 2004;83:341-7.

30. Thyfault JP, Hedberg EM, Anchan RM, Thorne OP, Isler CM, Newton ER, Dohm GL, deVente JE. Gestational diabetes is associated with depressed adiponectin levels. J Soc Gynecol Investig. 2005;12:41-5.

31. Ategbo JM, Grissa O, Yessoufou A, Hichami A, Dramane KL, Moutairou K, Miled A, Grissa A, Jerbi M, Tabka Z, Khan NA. Modulation of adipokines and cytokines in gestational diabetes and macrosomia. J Clin Endocrinol Metab. 2006;91:4137-43.

32. Bennett WL, Odelola OA, Wilson LM, Bolen S, Selvaraj S, Robinson KA et al. Evaluation of guideline recommendations on oral medications for type 2 diabetes mellitus: a systematic review. Ann Intern Med. 2012;156:27-36.

33. Sterne J. Pharmacology and mode of action of hypoglycaemic guanidine derivatives. In: Campbell GD. (ed.). Oral hypoglycaemic agents. London: Academic; 1969:193-245.

34. Dunaif A. Insulin resistance and the polycystic ovary syndrome: mechanism and implications for pathogenesis. Endocr Rev. 1997; 18:774-800.

35. Unlühizarci K, Keleştimur F, Bayram F, Sahin Y, Tutuş A. The effects of metformin on insulin resistance and ovarian steroidogenesis in women with polycystic ovary syndrome. Clin Endocrinol. 1999;51:231-6.

36. Lee A, Morley JE. Metformin decreases food consumption and induces weight loss in subjects with obesity with type II non-insulin-dependent diabetes. Obes Res. 1998;6:47-53.

37. Stumvoll M, Nurjhan N, Perriello G, Dailey G, Gerich JE. Metabolic effects of metformin in noninsulin-dependent diabetes mellitus. N Engl J Med. 1995;333:550-4.

38. Lustig RH. Hypothalamic obesity: the sixth cranial endocrinopathy. The Endocrinologist. 2002;12:2107.

39. Sigal RJ, El-Hashimy M, Martin BC, Soeldner JS, Krolewski AS, Warram JH. Acute post-challenge hyperinsulinemia predicts weight gain. Diabetes. 1997;46:1025-9.

40. Odeleye OE, de Courten M, Pettitt DJ, Ravussin E. Fasting hyperinsulinemia is a predictor of increased body weight gain and obesity in Pima Indian children. Diabetes. 1997;46:1341-5.

41. Bailey DJ, Turner RC. Metformin. N Engl J Med 1996;334:574-9.

42. Hermann LS, Melander A. Biguanides: basic aspects and clinical uses. In: Alberti KGMM, DeFronzo RA, Keen H, Zimmet P. (eds.). International textbook of diabetes mellitus. Vol. 1. Chichester, England: John Wiley; 1992:773-95.

43. Wang M, Tong JH, Zhu G, Liang GM, Yan HF, Wang XZ. Metformin for treatment of antipsychotic- 
induced weight gain: A randomized, placebocontrolled study. Schizophr Res. 2012;138:54-7.

44. Bushe CJ, Bradley AJ, Doshi S, Karagianis J. Changes in weight and metabolic parameters during treatment with antipsychotics and metformin: do the data inform as to potential guideline development? A systematic review of clinical studies. Int J Clin Pract. 2009;63:1743-61.

45. Seifarth C1, Schehler B, Schneider HJ. Effectiveness of metformin on weight loss in non-diabetic individuals with obesity. Exp Clin Endocrinol Diabetes. 2013;121(01):27-31.

46. Matsuda M, DeFronzo RA. Insulin sensitivity indices obtained from oral glucose tolerance testing: comparison with the euglycemic insulin clamp.

47. Derosa G, Maffioli P. Anti-obesity drugs: a review about their effects and their safety. Expert Opin Drug Saf. 2012;11:459-71.

48. Ara R, Blake L, Gray L, Hernández M, Crowther M, Dunkley A et al. What is the clinical effectiveness and cost-effectiveness of using drugs in treating obese patients in primary care? A systematic review. Health Technol Assess. 2012;16(5):iii-xiv, 1-195.

49. Levri KM, Slaymaker E, Last A, Yeh J, Ference J, D'Amico $F$ et al. Metformin as treatment for overweight and obese adults: a systematic review. Ann Fam Med. 2005;3:457-61.

50. Knowler WC, Barrett-Connor E, Fowler SE, Hamman RF, Lachin JM, Walker EA et al. Reduction in the incidence of type 2 diabetes with lifestyle intervention or metformin. $\mathrm{N}$ Engl J Med. 2002;346:393-403.

51. Diabetes Prevention Program Research Group. Longterm safety, tolerability, and weight loss associated with metformin in the diabetes prevention program outcomes study. Diabetes Care. 2012;35:731-72.

52. Fontbonne A, Diouf I, Baccara-Dinet M, Eschwege E, Charles MA. Effects of 1-year treatment with metformin on metabolic and cardiovascular risk factors in non-diabetic upper-body obese subjects with mild glucose anomalies: a post-hoc analysis of the BIGPRO1 trial. Diabetes Metab. 2009;35:38591.

53. Gambineri A, Patton L, Vaccina A, Cacciari M, Morselli-Labate AM, Cavazza C et al. Treatment with flutamide, metformin, and their combination added to a hypocaloric diet in overweight-obese women with polycystic ovary syndrome. J Clin Endocrinol Metab. 2006;91:3970-80.

54. Goodpaster BH, Kelley DE, Wing RR et al. Effects of weight loss on regional fat distribution and insulin sensitivity in obesity. Diabetes. 1999;48:839-84.

55. Glueck CJ, Fontaine RN, Wang P, Subbiah MT, Weber K, Illig E et al. Metformin reduces weight, centripetal obesity, insulin, leptin, and low-density lipoprotein cholesterol in nondiabetic, morbidly obese subjects with body mass index greater than 30 . Metabolism. 2001;50:856-61.

56. Lee A, Morley JE. Metformin decreases food consumption and induces weight loss in subjects with obesity with type II non-insulin-dependent diabetes. Obes Res. 1998;6(1):47-53.

57. Mogul HR, Peterson SJ, Weinstein BI, Southren AL. Long-term (2-4 year) weight reduction with metformin plus carbohydrate-modified diet in euglycemic, hyperinsulinemic, midlife women (Syndrome W). Heart Dis. 2003;5:384-92.

58. Dohm GL, Tapscott E, Pories W, Dabbs DJ, Flickinger EG, Meelheim D et al. An in vitro human muscle preparation suitable for metabolic studies. Decreased insulin stimulation of glucose transport in muscle from morbidly obese and diabetic subjects. J Clin Invest. 1988;82:486-94.

59. Butte NF. Carbohydrate and lipid metabolism in pregnancy: normal compared with gestational diabetes mellitus. American J Clin Nutrit. 2000;71(5):1256S-1S.

60. Catalano PM, Tyzbir ED, Roman NM, Amini SB, Sims EA. Longitudinal changes in insulin release and insulin resistance in nonobese pregnant women. American J Obstetr Gynecol. 1991;165:1667-72.

61. Catalano PM, Tyzbir ED, Wolfe RR, Roman NM, Amini SB, Sims EA. Longitudinal changes in basal hepatic glucose production and suppression during insulin infusion in normal pregnant women. American J Obstetr Gynecol. 1992;167:913-9.

62. Catalano PM, Tyzbir ED, Wolfe RR, Calles J, Roman NM, Amini SB, Sims EA. Carbohydrate metabolism during pregnancy in control subjects and women with gestational diabetes. American J Physiol. 1993;264:E60-7.

63. Kuhl C. Aetiology of gestational diabetes. Baillieres Clin Obstetr Gynaecol. 1991;5(2):279-92.

64. Ryan EA, O'Sullivan MJ, Skyler JS. Insulin action during pregnancy. Studies with the euglycemic clamp technique. Diabetes. 1985;34(4):380-9.

65. Buchanan TA, Metzger BE, Freinkel N, Bergman $\mathrm{RN}$. Insulin sensitivity and B-cell responsiveness to glucose during late pregnancy in lean and moderately obese women with normal glucose tolerance or mild gestational diabetes. American J Obstetr Gynecol. 1990;162(4):1008-4.

66. Lesser KB, Carpenter MW. Metabolic changes associated with normal pregnancy and pregnancy complicated by diabetes mellitus. Seminars in Perinatology. 1994;18(5):399-406.

67. Catalano PM, Nizielski SE, Shao J, Preston L, Qiao L, Friedman JE. Down regulated IRS-1 and PPAR gamma in obese women with gestational diabetes: relationship to FFA during pregnancy. American J Physiol Endocrinol Metabol. 2002;282(3):E522-33.

68. Schultes B, Oltmanns KM, Kern W, Fehm HL, Born $\mathrm{J}$, Peters A. Modulation of hunger by plasma glucose and metformin. J Clin Endocrinol Metab. 2003;88:1133-41.

69. Paolisso G, Amato L, Eccellente R, Gambardella A, Tagliamonte MR, Varricchio G et al. Effect of metformin on food intake in obese subjects. Eur $\mathrm{J}$ Clin Invest. 1998;28:441-6. 
70. Mick GJ, Wang X, Ling Fu C, McCormick KL. Inhibition of leptin secretion by insulin and metformin in cultured rat adipose tissue. Biochim Biophys Acta. 2000;1502:426-32.

71. Morin-Papunen LC, Koivunen RM, Tomas C, Ruokonen A, Martikainen HK. Decreased serum leptin concentrations during metformin therapy in obese women with polycystic ovary syndrome. J Clin Endocrinol Metab. 1998;83:2566-8.

Cite this article as: Ali Abd El Fattah E. Can metformin limit weight gain in the obese with pregnancy? Int J Reprod Contracept Obstet Gynecol 2016;5:818-25. 